Images in...

\title{
Survival of acute ST-elevation myocardial infarction with total occlusion of the left main coronary artery
}

\author{
Josef Friedenberger, Holger Thiele \\ Department of Cardiology/Angiology, Herzzentrum Leipzig, Leipzig, Germany
}

Correspondence to Josef Friedenberger, josef-friedenberger@gmx.net

\begin{abstract}
Summary
This image demonstrates the survival of a patient with total acute occlusion of the left main stem, which was treated by primary percutaneous coronary intervention (PCI). Before the patient was referred to the emergency room, she had already suffered from chest pain for about $11 \mathrm{~h}$. Remarkably, the patient survived the acute myocardial infarction despite extreme myocardial necrosis of $>60 \%$ of the left ventricle as demonstrated by delayed enhancement MRI. The attached images show angiography before and after PCl, the impressive initial ECG and delayed enhanced MRI with mainly transmural contrast enhancement.
\end{abstract}

\section{BACKGROUND}

This image demonstrates the survival of a patient with total acute occlusion of the left main stem, which was successfully treated by primary percutaneous coronary intervention (PCI).

The most remarkable feature was that the patient survived this acute myocardial infarction, a disease with in-hospital mortality of $36-55 \%$, despite extreme myocardial necrosis of $>60 \%$ of the left ventricle as demonstrated by delayed enhancement MRI. The attached images show angiography before and after PCI, the impressive initial ECG and delayed enhancement MRI.

\section{CASE PRESENTATION}

A 67-year-old woman was referred to emergency room because of chest pain, lasting for approximately $11 \mathrm{~h}$. The prehospital ECG showed ST-elevation in the leads characterising the anteroseptal and basolateral ventricle segments (figure 1A). At admission, the patient was in cardiogenic shock. Coronary angiography revealed total thrombotic occlusion (thrombolysis in myocardial infarction (TIMI) flow grade 0 ) of the left main coronary artery (figure $1 \mathrm{~B}$ ). Emergency angioplasty was successfully performed with stenting and final kissing-balloon dilation resulting in TIMI flow grade III (figure 1B), followed by intensive care unit (ICU) treatment with mechanical ventilation, high-dose catecholamines and intra-aortic balloon pump. Antibiotic therapy due to hospital-acquired pneumonia, acute renal failure requiring haemodialysis and critical illness polyneuropathy complicated the mobilisation process.

After successful ICU treatment, MRI was performed, confirming echocardiographic findings of an extremely reduced left ventricular ejection fraction of $24 \%$ (figure 1C). Delayed enhancement images after application of gadolinium-based contrast media visualised extensive mainly transmural contrast enhancement in the infarct regions (figure $1 \mathrm{C}$, arrows). Infarct size was $65 \%$ of total left ventricular mass.

Left ventricular ejection fraction did not recover substantially after 6 months. However, the patient survived fulminant myocardial infarction with total occlusion of left main stem - a disease with in-hospital mortality of $36-55 \%{ }^{12}-$ after suffering from chest pain for $11 \mathrm{~h}$. Left main stem occlusion need not be accompanied by pulmonary oedema, cardiogenic shock or cardiac arrest. Also worth mentioning is the alternative treatment option of emergent surgical revascularisation.

\section{OUTCOME AND FOLLOW-UP}

After 4 weeks of ICU management, the patient could be mobilised and released from the hospital. Left ventricular ejection fraction did not recover substantially after 6 months. Butshe survived myocardialinfarction with total occlusion of the left main stem, a disease with in-hospital mortality of $36-55 \%,{ }^{12}$ after suffering from chest pain for $11 \mathrm{~h}$.

\section{DISCUSSION}

The patient survived fulminant myocardial infarction with total occlusion of left main stem - a disease with in-hospital mortality of $36-55 \%{ }^{12}$ - after suffering from chest pain for $11 \mathrm{~h}$. Left main stem occlusion need not be accompanied by pulmonary oedema, cardiogenic shock or cardiac arrest. Also worth mentioning is the alternative treatment option of emergent surgical revascularisation. 


\section{BMJ Case Reports}

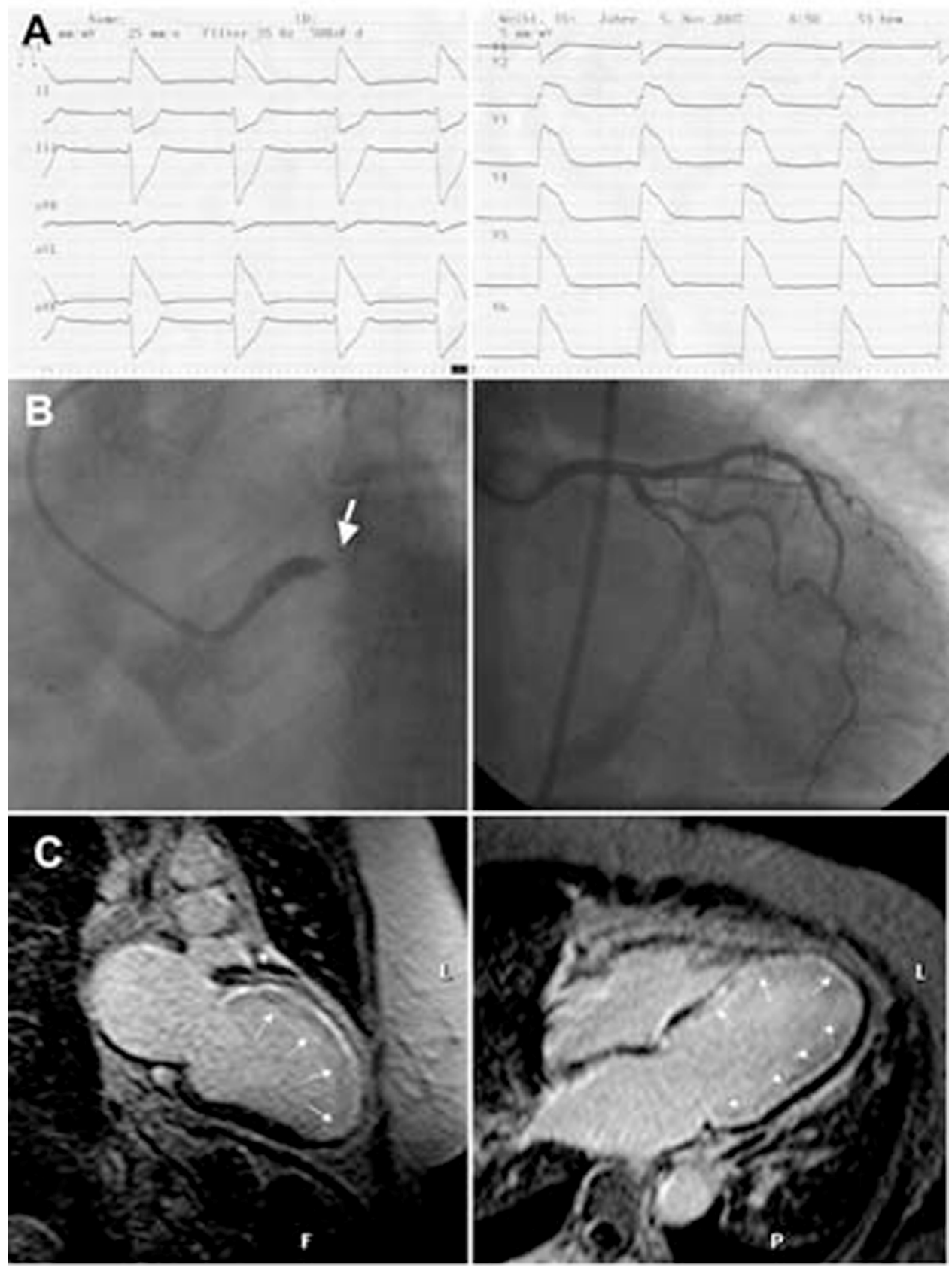

Figure 1 Prehospital ECG with ST-elevation in the leads characterising the anteroseptal and basolateral ventricle segments (A). Angiography before and after $\mathrm{PCI}(\mathrm{B})$. Delayed enhancement MRI images after application of gadolinium-based contrast media (C).

Learning points

- Survival of acute myocardial infarction with thrombotic occlusion of the left main stem.

- The possible options of $\mathrm{PCl}$ and surgical revascularisation.

- Importance of high-effort ICU management.

Competing interests None.
Patient consent Obtained.

\section{REFERENCES}

1. Prasad SB, Whitbourn R, Malaiapan Y, et al. Primary percutaneous coronary intervention for acute myocardial infarction caused by unprotected left main stem thromboses. Catheter Cardiovasc Interv 2009;73:301-7.

2. Marso SP, Steg G, Plokker T, et al. Catheter-based reperfusion of unprotected left main stem stenosis during an acute myocardial infarction (the ULTIMA experience). Unprotected Left Main Trunk Intervention Multicenter Assessment. Am J Cardiol 1999:83:1513-17. 


\section{BMJ Case Reports}

This pdf has been created automatically from the final edited text and images.

Copyright 2010 BMJ Publishing Group. All rights reserved. For permission to reuse any of this content visit http://group.bmj.com/group/rights-licensing/permissions.

BMJ Case Report Fellows may re-use this article for personal use and teaching without any further permission.

Please cite this article as follows (you will need to access the article online to obtain the date of publication).

Friedenberger J, Thiele H. Survival of acute ST-elevation myocardial infarction with total occlusion of the left main coronary artery. BMJ Case Reports 2010;10.1136/bcr.11.2009.2467, date of publication

Become a Fellow of BMJ Case Reports today and you can:

- Submit as many cases as you like

- Enjoy fast sympathetic peer review and rapid publication of accepted articles

Access all the published articles

- Re-use any of the published material for personal use and teaching without further permission

For information on Institutional Fellowships contact consortiasales@bmjgroup.com

Visit casereports.bmj.com for more articles like this and to become a Fellow 